\title{
In Vitro Effect of Low-Level Laser Therapy on Undifferentiated Mouse Pulp Cells
}

\section{Efeito in Vitro da Laserterapia de Baixa Intensidade em Células Pulpares Indiferenciadas de Camundongo}

Daniela Thomazatti Chimello-Sousa ${ }^{\text {a }}$ Karina Fittipaldi Bombonato-Prado ${ }^{\text {ab }}$; Adalberto Luiz Rosa ${ }^{\text {a }}$ Roger Rodrigo Fernandes $^{\mathrm{a}}$; Luciano Bachmannn; Selma Siéssere ${ }^{\mathrm{ab}}$; Marcelo Palinkas*abc; Geovane Praxedes Lavez ${ }^{\mathrm{a}}$; Simone Cecílio Hallak Regalo ${ }^{\mathrm{ab}}$

\author{
${ }^{a}$ University of São Paulo, School of Dentistry of Ribeirão Preto, Basic and Oral Biology Department. SP, Brazil \\ ${ }^{b}$ National Institute and Technology - Translational Medicine. SP, Brazil. \\ 'Faculty Anhanguera. SP, Brazil. \\ *E-mail: palinkas@usp.br \\ Recebido em: 03/09/2020 \\ Aprovado em: 02/12/2020
}

\begin{abstract}
Low-level laser therapy has been investigated as a possible stimulus for enhancement of proliferation and differentiation of various cell types, but few reports relate undifferentiated mouse pulp cells (OD-21) response to irradiation in in vitro models. The aim of this study was to analyze the influence of low-level laser therapy $(\lambda=660 \mathrm{~nm})$, with three different irradiation times, on the behavior of OD-21 cell line. The cells were cultivated and divided into three groups: non-irradiated/control (group I); irradiated with $88 \mathrm{~s}$ (group II); irradiated with $177 \mathrm{~s}$ (group III) and irradiated with $265 \mathrm{~s}$ (group IV). Cell growth and viability were assessed after 7 and 10 days. Data were analyzed by Kruskal-Wallis and MannWhitney tests $(\alpha=.05)$. At day 7 , there was a higher cell growth in groups I and II, as compared to group IV ( $p<.01)$. At the 10th day, group I showed a higher cell growth as compared to group II $(p<.05)$. Cell viability in group IV was significantly lower at the 7th day, as compared to groups I $(p<.001)$, II $(p<.01)$ and III $(p<.001)$. Cell viability in all the groups was over $80 \%$, except in group IV at day 7 . Irradiation time of group I influenced positively the proliferation and viability of OD-21 cells in late cell culture period.
\end{abstract}

Keywords: Low-Level Laser Therapy. Cell Culture. Stem Cells.

\section{Resumo}

A terapia a laser de baixa intensidade tem sido investigada como possível estímulo para aumento da proliferação e diferenciação de vários tipos de células, mas poucos relatos relacionam a resposta de células indiferenciadas da polpa dentária de camundongos (OD-21) à irradiação em modelos in vitro. $O$ objetivo deste estudo foi analisar a influência do laser de baixa intensidade $(\lambda=660 \mathrm{~nm})$, com três periodos de irradiação diferentes, no comportamento das células da linhagem OD-21. As células foram cultivadas e distribuídas em três grupos: não irradiado / controle (grupo I); irradiado com $88 \mathrm{~s}$ (grupo II); irradiado com $177 \mathrm{~s}$ (grupo III) e irradiado com $265 \mathrm{~s}$ (grupo IV). O crescimento e a viabilidade celular foram avaliados após 7 e 10 dias. Os dados foram analisados pelos testes de Kruskal-Wallis e Mann-Whitney ( $\alpha$ $=0,05)$. No dia 7, houve crescimento celular maior nos grupos I e II, em comparação ao grupo IV (p <0,01). No décimo dia, o grupo I apresentou crescimento celular superior ao grupo II $(p<0,05)$. A viabilidade celular no grupo IV foi significativamente menor no sétimo dia, em comparação aos grupos I ( $p<0,001)$, II ( $p<0,01)$ e III ( $p<0,001)$. A viabilidade celular em todos os grupos foi superior a $80 \%$, exceto no grupo IV no dia 7. O tempo de irradiação do grupo I influenciou positivamente a proliferação e a viabilidade das células OD-21 no período mais tardio da cultura celular.

Palavras-chave: Laserterapia de Baixa Intensidade. Cultura Celular. Células Tronco.

\section{Introduction}

Recent advances in tissue and cell engineering have been contributing to repair or regeneration of injured tissues, by using mesenchymal stem cells ${ }^{1,2}$, which have been known by the self-renewing properties (i.e., proliferation without a change in phenotype) and the capacity to differentiate into one or many different specialized cell types (i.e., changing into a new phenotype $)^{3}$. In the Dentistry field, stem cells derived from dental pulp have been isolated and investigated as possible sources for regeneration of injured tissues ${ }^{4,5}$.

Immortalized murine pulp cells $(\mathrm{OD}-21)^{6}$ are undifferentiated mesenchymal stem cells derived from fetal molar papillae ${ }^{7}$. It has been suggested that OD-21 lineage has potentiality to differentiate into odontoblast-like cells, under appropriate conditions, which might be a favorable source for pulp therapy. ${ }^{6}$

Low level laser therapy (LLLT), whose biomodulatory effects were firstly demonstrated by Mester et al. ${ }^{8}$, has been extensively investigated as a possible stimulus for enhancement

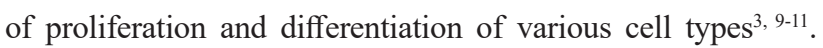

Low level lasers are light sources whose wavelengths are situated in red and near-infrared region of electromagnetic spectrum. The photobiological reactions at cellular level via the activation of mitochondrial respiratory chain are considered as the major action mechanism of those lasers. ${ }^{11}$ Although this mechanism has not been fully clarified, the most accepted theory is that photons of a specifically wavelength 
enter the cell and are readily absorbed by chromophores (such as cytochrome c oxidase) located either in the mitochondria or in the cell membrane, generating electronic excitation inside the respiratory chain, leading to an increase in oxidative metabolism ${ }^{12,13}$.

The photonic energy is converted to chemical energy within the cell, in the form of ATP, which enhances cellular functions and cell proliferation rates. Light situated at the visible red region of electromagnetic spectrum is absorbed by the mitochondria while near-infrared light is absorbed by the cellular membrane, causing alterations in permeability, increase in ATP levels and the synthesis of DNA, RNA, proteins, enzymes and other products needed to repair or regenerate the cell ${ }^{14}$.

The laser biomodulation effects magnitude depends on the wavelength used as well as the physiological cell state at the irradiation moment, that is, if the cellular environment is optimal or near optimal (nonpathological), the effects of LLLT will not be so pronounced ${ }^{15}$. The LLLT effects are also dependent of other parameters, such as time of irradiation, power, irradiance and number of applications ${ }^{16}$. Considering the LLLT biomodulatory properties and the lack of works focusing on the functional activity of OD-21 lineage after low level laser irradiation, the aim of this preliminary study was to evaluate in vitro the effect of a low-level laser, with a wavelength situated at the red region of electromagnetic spectrum, applied with different irradiation times, on murine undifferentiated pulp cells (OD-21), by means of the analysisculture growth and cell viability. The results of this investigation may contribute significatively with dental clinics, especially with Endodontics, with the hypothesis that low level laser therapy could stimulate the dental pulp cells differentiation in odontoblasts resulting in new dentin matrix, helping dentin repair after injuries such as traumas or caries lesions.

\section{Material and Methods}

\subsection{Cell culture}

The OD-21 cells were kindly granted by Professor Jacques Eduardo Nör and colleagues (School of Dentistry, The University of Michigan, USA) and were cultivated in $75 \mathrm{~cm}^{2}$ flasks containing Dulbecco's Modified Eagle's medium (DMEM, Gibco BRL, Grand Island, NY), supplemented with 10\% fetal bovine serum (Gibco, USA) and $100 \mathrm{IU} \mathrm{mL}^{-1}$ penicillin/50 $\mathrm{mg} \mathrm{mL}-1$ streptomycin in a humidified $5 \% \mathrm{CO}_{2}$ incubator at $37^{\circ} \mathrm{C}$. When they reached subconfluence, the cells were treated with $1 \mathrm{mM}$ EDTA (Gibco, USA) and 0.25\% trypsin (Gibco, USA), and subcultured in 24-well polystyrene plates (Falcon, Franklin Lakes, NJ) at a density of $10^{4}$ cells/well $(n=5)$. Each experimental group was cultured in different plates, and the cell cultures were distributed in five wells at an adequate distance from each other to avoid undesirable irradiation adjacently. DMEM supplemented with $10 \%$ fetal bovine serum, $100 \mathrm{IU}$ $\mathrm{mL}^{-1}$ penicillin $/ 50 \mathrm{mg} \mathrm{mL}^{-1}$ streptomycin, $5 \mu \mathrm{g} / \mathrm{mL}$ ascorbic acid (Gibco) and $7 \mathrm{mM} \beta$-glycerophosphate (Sigma-Aldrich, St. Louis, MO) were added to each well. Control (non-irradiated) and irradiated groups were harvested at the same manner. Culture medium from all the plates was changed every two days. Distribution of the experimental groups is presented in Table 1.

Table 1- Distribution of the experimental groups.

\begin{tabular}{|c|c|}
\hline Group & Treatment \\
\hline I & Non-irradiated (control) \\
II & Irradiated $(88 \mathrm{~s})$ \\
\hline III & Irradiated $(177 \mathrm{~s})$ \\
\hline IV & Irradiated $(265 \mathrm{~s})$ \\
\hline
\end{tabular}

Source: Research data.

\subsection{Laser irradiation}

An interval of $24 \mathrm{~h}$ was waited before the first irradiation, for cell adhesion at the base of the wells. The irradiation sessions occurred by completing the first and second days of culture. Low-level laser irradiation was performed using an Indium Gallium Aluminum Phosphide (InGaAlP) diode laser (Twin Flex Evolution, MM Optics, São Carlos, SP, Brazil) emitting a wavelength light of $660 \mathrm{~nm}$ (at the red region of the electromagnetic spectrum) in continuous mode. The laser beam was expanded with the aid of a 20x magnification objective lens (Carl Zeiss Meditec, Jena, Germany) attached to the conventional laser handpiece, in order to perform irradiation of the entire surface of each well at the same time. Laser was applied with the aid of a support device, specially developed for this purpose, which held the emission tip firmly, thus standardizing the irradiation distance. The distance between the beam output and the bottom of the culture plates was $13.3 \mathrm{~cm}$ and the light was concentrated in an area of $2.3 \mathrm{~cm}^{2}$, allowing a uniform irradiation of the cell monolayer. Control and irradiated groups were exposed to the same conditions such as temperature, humidity, time outside the incubator and light, being the plates covered by a black box during irradiation, exposing only the area to be irradiated. During irradiation, the plates were maintained inside the laminar flow, and the laser irradiation was performed by only one operator. The real power delivered by the laser device was periodically checked with the aid of a powermeter (FieldMaster, Coherent, Santa Clara, CA). Irradiation parameters are presented in Table 2.

Table 2- Irradiation parameters

\begin{tabular}{|l|c|c|c|}
\hline \multirow{2}{*}{} & \multicolumn{3}{|c|}{ Groups } \\
\cline { 2 - 4 } & II & III & IV \\
\hline Power at equipment display $(\mathrm{mW})$ & 40 & 40 & 40 \\
Output power $(\mathrm{mW})$ & 26 & 26 & 26 \\
\hline Irradiance $\left(\mathrm{mW} / \mathrm{cm}^{2}\right)$ & 11.3 & 11.3 & 11.3 \\
\hline Energy density $\left(\mathrm{J} / \mathrm{cm}^{2}\right)$ & 1 & 2 & 3 \\
\hline Number of sessions $(24-h$ interval) & 2 & 2 & 2 \\
\hline Total cumulative energy/well $(\mathrm{J})$ & 4.6 & 9.2 & 13.8 \\
\hline
\end{tabular}

Source: Research data.

\subsection{Cell number and viability}

The Trypan blue exclusion assay was used to determine the total number of cells and cell viability of non-irradiated and irradiated cells after 7 and 10 days in culture. This is a standardized protocol already used previously in our laboratory. ${ }^{17}$ Briefly, cells were enzymatically detached using 
$1 \mathrm{mM}$ EDTA and $0.25 \%$ trypsin solution. After Trypan blue staining, the number of viable and unviable cells were counted using a hemocytometer. Cell growth was expressed as total number of cells x $10^{4}$ per well. Cell viability was determined as percentage of viable cells.

\subsection{Statistical analysis}

The statistical analysis was performed using IBM SPSS Statistics for Windows, version 21.0 (IBM SPSS, IBM Corp., Armonk, NY, USA). Data were compared by the KruskalWallis test followed by the Mann-Whitney test, being the level of significance established at $p<.05$

\section{Results and Discussion}

The present study aimed to assess the influence of different irradiation times on OD-21 lineage by means of cell growth and viability. Because this was a preliminary study, other cellular functions were not analyzed at this time.

Figure 1 shows that cells proliferated increasingly from $7^{\text {th }}$ to $10^{\text {th }}$ day. At day $7^{\text {th }}$, there was a higher cell growth in groups I and II, as compared to group IV $(p<.01)$. At the $10^{\text {th }}$ day, group I showed a higher cell growth as compared to group II $(p<.05)$. Figure 2 shows that cell viability in group IV was significantly lower at the $7^{\text {th }}$ day, as compared to groups I $(p<.001)$, II $(p<.01)$ and III $(p<.001)$. Cell viability in all the groups was over $80 \%$, except in group IV at day 7 .

Figure 1- Proliferation of mouse undifferentiated pulp cells (OD21) after different irradiation times

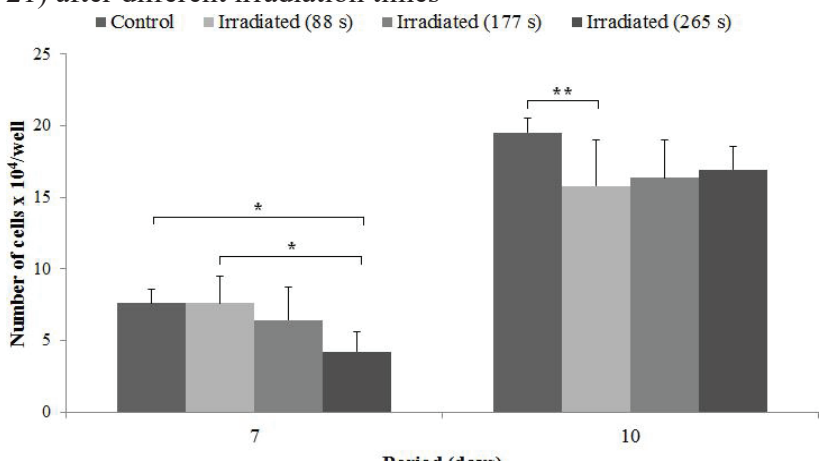

Kruskal-Wallis test followed by Mann-Whitney test $\left({ }^{*} \mathrm{p}<.01 ;{ }^{* *} \mathrm{p}<.05\right)$. Source: Research data.

Figure 2- Viability of mouse undifferentiated pulp cells (OD-21) after different irradiation times

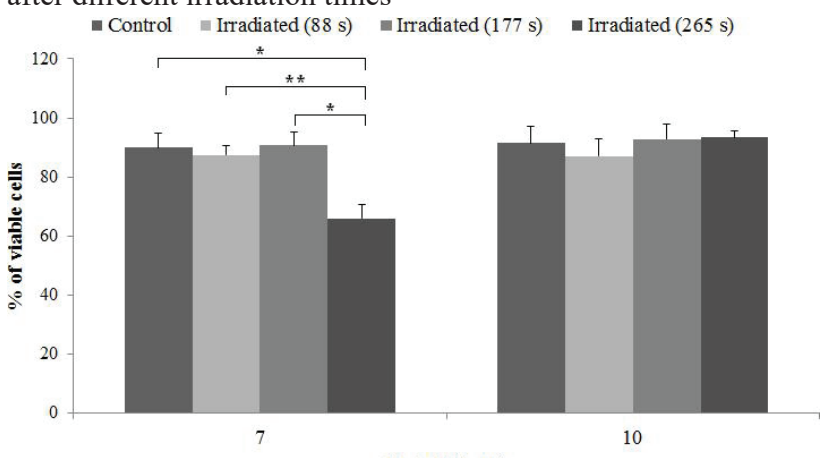

Period (days)

Kruskal-Wallis test followed by Mann-Whitney test $\left({ }^{*} p<.001 ;{ }^{*} p<.01\right)$. Source: Research data.
Cellular environmental conditions and irradiation parameters have been reported to be determinant factors for light-induced biological effects ${ }^{14}$. Although some authors showed that laser irradiation presented better effects on stressed cells ${ }^{15,18}$, in the present experiment cells were cultured without nutritional stress, that is, the culture medium was supplemented with fetal bovine serum at an adequate percentage for normal cell growth ${ }^{19}$. The addition of ascorbic acid and $\beta$-glycerophosphate to the culture medium (biochemical inducers) aimed to stimulate OD-21 cells differentiation ${ }^{20}$.

Regarding laser parameters, the wavelength of 660 $\mathrm{nm}$ (InGaAlP laser), situated at the visible red region of the electromagnetic spectrum, was chosen because of its shallower penetration as compared to the near infrared lasers, since irradiation was performed directly to the cell monolayer, with no need for a deep penetration. The output power and irradiance were kept fixed while the time of irradiation varied, thus causing a variation in the energy density and in the total cumulative energy per well. Several studies investigated the effects of LLLT on cell cultures employing different irradiation times and energy densities, keeping output power and irradiance fixed ${ }^{21,22}$.

Laser application was performed through the bottom of the optically clear 24-well plates. Therefore, the laser beam did not transpose the culture medium, being applied straight onto the cell monolayer at a fixed distance ${ }^{3}$. For this purpose, a device that could expand the laser beam and irradiate the entire well area was used. Irradiation using the original laser spot size $\left(0.04 \mathrm{~cm}^{2}\right)$ would result in multiple points of application, which would be unviable due to the difficulty irradiating the cells uniformly and the considerable increase of total irradiation time. The expanded beam showed to be uniform, with a loss of around $35 \%$ of its original power, due to the lens assembly presence and the culture plate acrylic. The output power was periodically checked by means of a power meter. Finally, laser irradiation was carried out in partial darkness without light influence other than laser ${ }^{3}$.

According to the results of the present study, the shortest irradiation time (88 s), comprising $1 \mathrm{~J} / \mathrm{cm}^{2}$ energy density, resulted in a lower cell growth after 10 days in culture, without adversely affect the cell viability, as compared to the nonirradiated group. A decrease in cell proliferation rate without affecting cell viability was also reported by Pereira et al. ${ }^{17}$, after irradiating a mouse odontoblast-like cell line (MDPC-23) with an infra-red laser $\left(830 \mathrm{~nm}, 25.5 \mathrm{~mW}, 85 \mathrm{~mW} / \mathrm{cm}^{2}, 10 \mathrm{~s}, 0.8 \mathrm{~J} /\right.$ $\mathrm{cm}^{2}$ ). Nogueira et al. ${ }^{23}$ also observed that LLLT (780 nm, 10 $\mathrm{mW}, 3 \mathrm{~J} / \mathrm{cm}^{2}$, total energy $0.12 \mathrm{~J}$ ), in combination with a high concentration of steroid, inhibited osteoblasts proliferation. The cell growth restriction might be related to the beginning of cell differentiation, as suggested by other authors ${ }^{24}$. According to Andreeff et al. ${ }^{25}$, stem cell differentiation results in two types of changes: the expression of specialized, differentiation-specific gene products and a partial or complete 
restriction of the cell's capacity for further proliferation. The longest irradiation time (265 s), corresponding to an energy density of $3 \mathrm{~J} / \mathrm{cm}^{2}$, resulted in a lower cell growth at the seventh day, with a considerable decrease in cell viability, suggesting that these parameters could have affected somehow the cell cycle in this period. These results differed from others, in which cells irradiated with low level laser presented a higher proliferation rate than non-irradiated cells ${ }^{3,26,27}$. Meanwhile, other studies demonstrated that irradiation with low-level laser did not interfere significantly in cell viability and proliferation as compared with the non-irradiated controls. Differences in methodology, such as cell type, cell culture conditions, wavelength and irradiation parameters, might have contributed to the divergences in the results. However, most authors agreed with the fact that lower energy densities were better for cell stimulation ${ }^{28}$.

\section{Conclusion}

It can be concluded that, within the conditions and limits of the present study, the irradiation time of 88 seconds, irradiance of $11.3 \mathrm{~mW} / \mathrm{cm}^{2}$, energy density of $1 \mathrm{~J} / \mathrm{cm}^{2}, 2$ sessions and total energy of $4.6 \mathrm{~J}$ influenced positively the proliferation and viability of OD-21 cells in late culture period (10 days). However, further studies are necessary for the establishment of the best irradiation parameters for OD-21 lineage, by means of the analysis of other cellular functions, as well as of differentiation markers.

\section{Aknowledgments}

FAPESP (The State of São Paulo Research Foundation) for financial support (processes No. 2008/58600-5, 2010/09918-2 and 2010/50086-0) and Professor Jacques Eduardo Nör and colleagues (School of Dentistry, The University of Michigan, USA) for kindly grant the OD-21 cell line.

\section{References}

1. Uccelli A, Moretta L, Pistoia V. Mesenchymal stem cells in health and disease. Nat Rev Immunol 2008;8(9):726-36. doi: $10.1038 /$ nri2395

2. Atiya H, Frisbie L, Pressimone C, Coffman L. Mesenchymal stem cells in the tumor microenvironment. Adv Exp Med Biol 2020;1234:31-42. doi: 10.1007/978-3-030-37184-5 3

3. Eduardo FP, Bueno DF, Freitas PM, Marques MM, PassosBueno MR, Eduardo CP, et al. Stem cell proliferation under low intensity laser irradiation: a preliminary study. Lasers Surg Med 2008;40(6):433-8. doi: 10.1002/lsm.20646

4. Caruso S, Sgolastra F, Gatto R. Dental pulp regeneration in paediatric dentistry: the role Shah D, Lynd T, Ho D, Chen J, Vines J, Jung HD, et al. Pulp-Dentin Tissue Healing of stem cells. Eur J Paediatr Dent 2014;15(2):90-4.

5. Response: a discussion of current biomedical approaches. J Clin Med. 2020;9(2). pii: E434. doi: 10.3390/jcm9020434

6. Zanini M, Sautier JM, Berdal A, Simon S. Biodentine induces immortalized murine pulp cell differentiation into odontoblast-like cells and stimulates biomineralization. J Endod 2012;38(9):1220-6. doi: 10.1016/j.joen.2012.04.018
7. Hanks CT, Fang D, Sun Z, Edwards CA, Butler WT. Dentinspecific proteins in MDPC-23 cell line. Eur J Oral Sci 1998;106 Suppl 1:260-6

8. Mester E, Spiry T, Szende B, Tota JG. Effect of laser rays on wound healing. Am J Surg 1971;122(4):532-5.

9. Ferriello V, Faria MR, Cavalcanti BN. The effects of low-level diode laser treatment and dental pulp-capping materials on the proliferation of L-929 fibroblasts. J Oral Sci 2010;52(1):33-8.

10. Yin K, Zhu R, Wang S, Zhao RC. Low-Level Laser Effect on Proliferation, Migration, and Antiapoptosis of Mesenchymal Stem Cells. Stem Cells Dev 2017;26(10):762-75. doi: $10.1089 /$ scd.2016.0332

11. Khorsandi K, Hosseinzadeh R, Abrahamse H, Fekrazad R. Biological Responses of Stem Cells to Photobiomodulation Therapy. Curr Stem Cell Res Ther 2020. doi: 10.2174/157488 $8 X 15666200204123722$

12. Huang YY, Sharma SK, Carroll J, Hamblin MR. Biphasic dose response in low level light therapy - an update. Dose Response 2011;9(4):602-18. doi: 10.2203/dose-response.11-009. Hamblin

13. Kiro NE, Hamblin MR, Abrahamse H. Photobiomodulation of breast and cervical cancer stem cells using low-intensity laser irradiation. Tumour Biol 2017;39(6):1010428317706913. doi: $10.1177 / 1010428317706913$

14. Gao X, Xing D. Molecular mechanisms of cell proliferation induced by low power laser irradiation. J Biomed Sci 2009;16:4. doi: 10.1186/1423-0127-16-4

15. Hawkins DH, Abrahamse H. The role of laser fluence in cell viability, proliferation, and membrane integrity of wounded human skin fibroblasts following helium-neon laser irradiation. Lasers Surg Med 2006;38(1):74-83

16. Haxsen V, Schikora D, Sommer U, Remppis A, Greten J, Kasperk C. Relevance of laser irradiance threshold in the induction of alkaline phosphatase in human osteoblast cultures. Lasers Med Sci 2008;23(4):381-4.

17. Pereira LB, Chimello DT, Ferreira MR, Bachmann L, Rosa AL, Bombonato-Prado KF. Low-level laser therapy influences mouse odontoblast-like cell response in vitro. Photomed Laser Surg 2012;30(4):206-13. doi: 10.1089/pho.2011.3087

18. Azevedo LH, de Paula Eduardo F, Moreira MS, de Paula Eduardo C, Marques MM. Influence of different power densities of LILT on cultured human fibroblast growth : a pilot study. Lasers Med Sci 2006;21(2):86-9.

19. Semeghini MS, Fernandes RR, Chimello DT, de Oliveira FS, Bombonato-Prado KF. In vitro evaluation of the odontogenic potential of mouse undifferentiated pulp cells. Braz Dent J 2012;23(4):328-36.

20. Musson DS, McLachlan JL, Sloan AJ, Smith AJ, Cooper PR. Adrenomedullin is expressed during rodent dental tissue development and promotes cell growth and mineralization. Biol Cell 2010;102(3):145-57. doi: 10.1042/BC20090122

21. Soleimani M, Abbasnia E, Fathi M, Sahraei H, Fathi Y, Kaka $\mathrm{G}$. The effects of low-level laser irradiation on differentiation and proliferation of human bone marrow mesenchymal stem cells into neurons and osteoblasts--an in vitro study. Lasers Med Sci 2012;27(2):423-30. doi: 10.1007/s10103-011-09301

22. Bayat M, Jalalifirouzkouhi A. Presenting a Method to Improve Bone Quality Through Stimulation of Osteoporotic Mesenchymal Stem Cells by Low-Level Laser Therapy. Photomed Laser Surg 2017;35(11):622-28. doi: 10.1089/ 
pho. 2016.4245

23. Nogueira GT, Mesquita-Ferrari RA, Souza NH, Artilheiro PP, Albertini R, Bussadori SK, et al. Effect of low-level laser therapy on proliferation, differentiation, and adhesion of steroid-treated osteoblasts. Lasers Med Sci 2012;27(6):118993. doi: 10.1007/s10103-011-1035-6

24. Bellesini LS, Beloti MM, Crippa GE, Bombonato-Prado KF, Junta CM, Marques MM, et al. The effect of TAK-778 on gene expression of osteoblastic cells is mediated through estrogen receptor. Exp Biol Med (Maywood) 2009;234(2):190-9. doi: 10.3181/0808-RM-246

25. Andreeff M, Goodrich DW, Pardee AB. Cell proliferation, differentiation, and apoptosis. In: Bast RC, Kufe DW, Pollock RE, Weichselbaum RR, Holland JF, Frei E. HollandFrei cancer medicine. Hamilton: BC Decker; 2000.
26. Horvát-Karajz K, Balogh Z, Kovács V, Drrernat AH, Sréter L, Uher F. In vitro effect of carboplatin, cytarabine, paclitaxel, vincristine, and low-power laser irradiation on murine mesenchymal stem cells. Lasers Surg Med 2009;41(6):463-9. doi: 10.1002/lsm.20791

27. Castilho-Fernandes A, Lopes TG, Ferreira FU, Rezende N, Silva VF, Primo FL, et al. Adipogenic differentiation of murine bone marrow mesenchymal stem cells induced by visible light via photo- induced biomodulation. Photodiagnosis Photodyn Ther 2019;25:119-27. doi: 10.1016/j.pdpdt.2018.11.013

28. Incerti Parenti S, Panseri S, Gracco A, Sandri M, Tampieri A, Alessandri Bonetti G. Effect of low-level laser irradiation on osteoblast-like cells cultured on porous hydroxyapatite scaffolds. Ann Ist Super Sanita 2013;49(3):255-60. doi: 10.4415/ANN_13_03_04 